\title{
ECOLOGICAL SIGNIFICANCE OF SOME KENOPHYTES IN LOWER SILESIAN NATIONAL PARKS
}

\author{
JERZY FABISZEWSKI, TERESA BREJ \\ Department of Botany and Plant Ecology \\ University of Natural Sciences \\ pl. Grunwaldzki 24a, 50-363 Wrocław, Poland \\ e-mail: teresa.brej@up.wroc.pl
}

(Received: March 29, 2007. Accepted: October 26, 2007)

\begin{abstract}
The paper presents the results of several years investigations (2003-2007) on two invaders: the Himalayans Impatiens glandulifera and Asiatic Reynoutria japonica. The Sudety Mountains and their national parks are under strong pressure of both species, threatening the local vegetation. The four-year investigations have been carried out in field, glasshouse and in laboratory. Invasive species have their peculiar life histories which help them to occupy new areas. Those are above all the specific generative reproduction strategies (Impatiens) or vegetative reproduction strategies (Reynoutria). Both strategies secure the reproductive success and to capture more and more highly situated areas of the mountains. Very significant characteristics connected with the expansion of invaders is the excessively over and above the average production of seeds (Impatiens) and a huge annual increment aboveground biomass (Reynoutria). The investigated invasive species are probably not equipped with influence of allelopatic type as of greater importance is their competitive strength. The invaders can eliminate a part of the early spring flora belonging to the geophyte group and impoverish the regional biological diversity. Both the invasive plants enter also into some moist mountain forest communities.
\end{abstract}

KEY WORDS: The Sudety Mts, national parks, invasive species, Impatiens glandulifera, Reynoutria japonica, invasiveness, habitat preference.

\section{INTRODUCTION}

Biological invasions by non-native species have become a major environmental problem and a focus of ecological research (Crawley 1985; Mooney and Drake 1986; Di Castri et al. 1989; Drake et al. 1986; De Wall et al. 1994; Crank and Fuller 1995; Brock et al. 1997; Starfinger et al. 1998; Nentwig 2007). Most problems connected with invasiveness are already of a decisively global and even economic size (Londsale 1999; Theoharides and Dukes 2007).

Also in Poland the influence of anthropopressure - in that the mass expansion of invaders, leads to a so far unknown transformation of the vegetation cover, decline of numerous plant communities and retreat of numerous local peculiar species (Faliński 1998; Zając and Zając 1998; Tokarska-Guzik 2007). Our previous studies carried out in the Sudety (Fabiszewski and Kwiatkowski 2001; Fabiszewski and Brej 2005, 2007) indicated a direct influence of invasive species on the decline of biological variability in local phytocenoses. The mentioned papers include data on biology of the most aggressive invaders: the species of Reynoutria japonica s.l. of Japanese origin, and the Asian Impatiens glandulifera. In these articles discussed are also several hypotheses generalizing the issue of invasiveness and their application to local ecological conditions. We tried to answer the recently put question by the Canadian ecologists (MacDougall and Turkington 2005): "are invasive species the drivers or passengers of change in degraded ecosystems"? We analyzed also some of the hypotheses on reasons of success of invasive plants in the Sudety Mts. Our suggestions headed towards to recognizing as the most favorable for invasion success of the species analyzed in the Sudety: the phenomenon of strong propagule pressure, and the simultaneously progressing in local habitats anthropogenic disturbances (see review Hierro et al. 2005). Because of lack of data we unfortunately could not take a position on the interesting view of Pyšek and Richardson (2007), which combines the concentration and migration of invaders with time of their arrival and residence time.

In the present article we summarize the results of the several years studies in the Sudety on threat of invaders belonging to the genus Reynoutria ssp. and Impatiens glandulifera. We hope, that the results of our investigations will be of interest to the services of the two national parks in the Sudety: Karkonoski National Park and the Stołowe Mts National Park. 


\section{METHODS}

The field studies were carried out in the two mentioned national parks in the years 2005-2007. Our attention was focused on two kenophytes: the Himalayan Balsam Impatiens glandulifera Royle and the Japanese Knotweed Reynoutria japonica s.1. Both the species are intensively colonizing the lower situated territories in the Sudety. In the Karkonosze Mts their expansion reaches up to \pm 850 $\mathrm{m}$ above sea level (Fig. 1). In the latter area they become a threat to the local flora, decreasing thereby the botanical values of the Karkonosze National Park. All experiments were carried out in field - except the test concerning seed vigor. The main field works were performed in the years 2006 and 2007. All observations and collection of plant samples and their fragments - both generative and vegetative - were performed on constant surfaces, $2 \times 2 \mathrm{~m}$ in size. For every invasive species determined were 12 surfaces in each type of habitat. For further observation selected were 7 various habitats of the two analysed species: (1) in water of less swift streams; (2) in tall herbs communities with predominance of Senecio nemorensis, Petasites hybridus, P. albus; (3) in a hydrophilous Alno-Padion, community situated by a stream; (4) in a fertile beech forest Dentario (enneaphyllidis) - Fagetum; (5) in a low mountain belt forest with Picea abies and Abies alba; (6) in a Picea abies cultivation, deprived of forest floor, with thick not decom- posed forest litter; and (7) on a forest track, with plants belonging to the Plantaginetea class. For determination of vegetative vigour of kenophytes, in the selected 7 communities twice a year (in spring and in autumn) whole rhizomes as well as their cut fragments were scattered. The material for analysis collected was rhythmically 7 times in each year: from May 15 to October 27. The study results are presented in Tables and Figures included in the paper. For determination of biomass standard methods were used. Plant rhizomes were dried 48 hours in temperature of $85^{\circ} \mathrm{C}$, and next weighed. In experiments on germination of Impatiens glandulifera fully mature and healthy seeds were used (Table 1).

\section{RESULTS}

The description of results concerning two of the analyzed kenophytes heads toward the presentation of differences between the habitats preferred by the species. These differences derive from biological properties of the plants described. These properties decide on different life histories and ecological strategies of the kenophytes analyzed. Some biological properties, with decide on local habitat preferences and life strategies of the two analyzed invaders are presented below (Wade 1997).

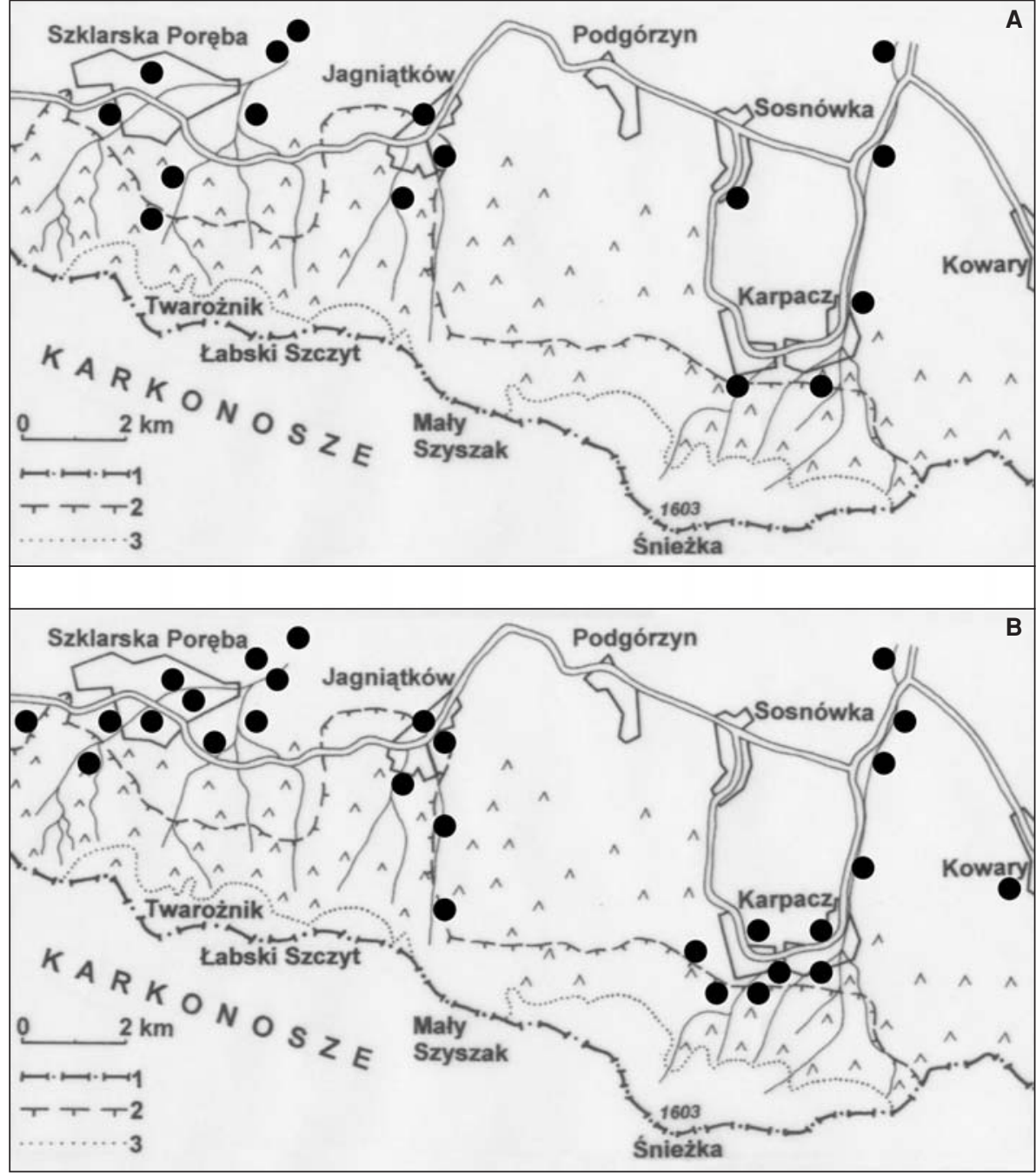

Fig. 1. Distribution of clusters of two inviders in the Karkonosze Mts. A - Impatiens glandulifera (one point mean over 20 individuals); B - Reynoutria japonica (one point mean over 3 clones); 1 - border of country; 2 - border of Karkonosze National Park; 3 upper forest limit. 
TABLE 1. Means of vegetative and reproductive traits of Impatiens glandulifera in different habitats (1-7) in the Karkonosze Mts.

\begin{tabular}{|c|c|c|c|c|c|c|c|}
\hline Habitat number & 1 & 2 & 3 & 4 & 5 & 6 & 7 \\
\hline Above-ground biomass ( $\mathrm{g}$ ) & $56.3 \pm 3.1$ & $59.7 \pm 6.1$ & $51.3 \pm 2.8$ & $37.2 \pm 4.9$ & $31.4 \pm 6.3$ & $29.1 \pm 6.1$ & $31.4 \pm 7.2$ \\
\hline Plant hight $(\mathrm{cm})$ & $112.3 \pm 4.2$ & $131.4 \pm 7.2$ & $110.4 \pm 3.7$ & $87.9 \pm 3.8$ & $81.3 \pm 6.1$ & $72.3 \pm 4.7$ & $79.3 \pm 4.8$ \\
\hline Time of flowering (days) & $72.3 \pm 7.1$ & $83.2 \pm 4.7$ & $87.2 \pm 7.1$ & $94.3 \pm 7.4$ & $99.4 \pm 7.2$ & $98.9 \pm 7.2$ & $81.4 \pm 7.3$ \\
\hline Individual density $\left(\mathrm{m}^{2}\right)$ & $60.0 \pm 3.1$ & $74.3 \pm 2.9$ & $37.4 \pm 4.8$ & $11.2 \pm 4.3$ & $16.3 \pm 4.2$ & $10.3 \pm 3.4$ & $10.2 \pm 3.1$ \\
\hline Pot number (per indiv.) & $12.7 \pm 3.4$ & $25.7 \pm 4.8$ & $17.8 \pm 3.7$ & $8.2 \pm 3.7$ & $7.3 \pm 2.7$ & $3.8 \pm 2.1$ & $10.0 \pm 2.8$ \\
\hline Seed number (per pot) & $8.2 \pm 2.3$ & $5.3 \pm 1.4$ & $9.1 \pm 1.8$ & $7.2 \pm 3.0$ & $4.3 \pm 1.8$ & $3.2 \pm 2.2$ & $5.0 \pm 1.8$ \\
\hline
\end{tabular}

Explanations: time of flowering - till September 20 (2006 and 2007); pot no. and seed no. - till end of October 2006 (N=50). Habitats: 1 - open stream water; 2 - tall herb community; 3 - periodically flooded forest of Alno-Padion; 4 - fertile black-forest Dentario (eneaphyllidis) - Fagetum; 5 - low mountain belt forest ("Piceetum", sporadically with fair Abies alba); 6 - plantation of Picea abies, no herb layer, thick cover of litter; 7 - forest road of Plantaginetea community. $(\mathrm{N}=15)$.

\section{Impatiens glandulifera Royle (Fig. 2, Fig. 3)}

Table 1 allows to determine the ecological status of Himalayan Balsam on the territory of the Karkonosze and to recognize its habitat preferences. The biomass and height of shoots confirm that the optimum of favourable conditions is situated near water habitats, and reaches even the slow streams (Berling and Perrins 1993; Pyšek and Prack 1995; Willis and Hulme 2004). The species Impatiens, which does not tolerate shade, penetrates - apart of flooded forests - only occasionally the local mesophilous forest. Therefore, its biomass and the gained height of shoots are rather small in the low mountain belt and in spruce cultivation, where its seeds have been introduced successfully. The site on the forest track (No. 7) is sufficiently insolated to assure good conditions - however, it is probably too dry to assure a constant saturation of the plant shoots with water. Full flowering is difficult to specify, because the invader blooms de facto for three months, bringing at the same time fruits and seeds. This secures the sequence of blooming, starting with top florets and - the rarely met in other species earlier development of distal flowers (and than fruits!), as compared with the delayed blooming of the proximal shoot axis. The concentration of individuals is confirmed by the hygrophilous character of the plant, yet indicating of the fact that individuals living in streams form thin concentrations, most probably connected with difficulties of seedlings' recruitment in difficult conditions of stony stream beds. In that respect, as optimal in settling communities of tall herbs growing on steams and fragments of flooded forests ought to be recognized. For seedlings' recruitment of importance are not only the nearness of water, but also a poor concentration of local plants allowing filling the free niches (Parings et al. 1993; Cullman and Bibulous 2004). The riverbed habitat is subject to continuous disturbances, what is conductive to the origin of areas ready for location of Impatiens seeds, particularly in places of distinct erosion. Earlier results concerning the numbers of pods and seeds (Fabiszewski and Brej 2005), as well as the currently presented ones, are in concordance with the picture of Impatiens glandulifera as an effective invader. The found number of seeds in pods is not high, but one ought to have regard to their almost permanent production (from July to October). The previous study results (Fabiszewski and Brej 2005, 2007) revealed a high seed vigour in seed germination of Impatiens glandulifera, making 60 to $90 \%$, preceded by the winter stratification. Furthermore, one should also mention the ballistic way of dissemination (after some authors - even at distance of $5 \mathrm{~m}$ ), as well as, the considerable weight of the seeds making on average 22 mg (Willis and Hume 2004). The problem of seed vitality is controversial. According to some ecologists it is rather high, particularly if the seeds are buried in bedding or in the upper soil layer (Berling and Perrins 1993). The lack of univocal views concerns also the presence or absence of a persistent seed bank in Impatiens. The cited above Berling and Parrins (1.c) think that the invader forms a seed bank, which can last out up to 18 month.

To convince oneself on the vitality of vegetative shoots of Impatiens, the plants torn out with roots where scattered in May and June in various plant communities - from streams, to fragments of beech and spruce forest. It appeared, that from 10 do $20 \%$ of Impatiens individuals, particularly in conditions of rainy weather, in some of the habitats took root in the two lower nodes. The process of rooting increased in case when the plants where covered by a thin layer of bedding or soil. Thus, one can conclude, that the spring erosion of streams, connected with carrying away plant fragments, may be of importance in expanding the invader's area. However, drought hinders that way of its dissemination. Our field experiments have shown highest ability for seed germination and seedlings, in turn: in slower streams, in tall herb communities with Petasites spp. and Senecio nemorensis, and in the Alno-Padion community, and in the fertile beech forest. During our field studies we did not find a univocal impact of the invader on extinction of local species. We only cursorily noticed its influence on growth reduction in Mercurialis perennis and a distinct yellowing of shoots in Galium rotundifolium. Table 1 confirms the thesis that Impatiens invades more and more higher parts of the Karkonosze Mts (Fabiszewski and Brej 2007). The local rivers and streams create a perfect way for enlargement of sites of this plant. The more and more frequent reports on possibility of competitive elimination by the invader of some herbs (Maule et al. 2000), as well as our own observations confirm, that the migration of Impatiens glandulifera in the Karkonosze Mts becomes highly undesirable, and that the invader should be fought against.

\section{Reynoutria japonica s.1. (Fig. 4, Fig. 5)}

To simplify the complicated taxonomical problems yielded by the related species of genus Reynoutria, we treated the Japanese Knotweed as a collective species. However, it is certain that in the Sudety at least two species occur: $R$. japonica Hout, and rarely $R$. sachalinensis. Reynoutria japonica the rhizomatic, clonal geophyte became recently an inherent element of the Sudety landscape. It expands along 


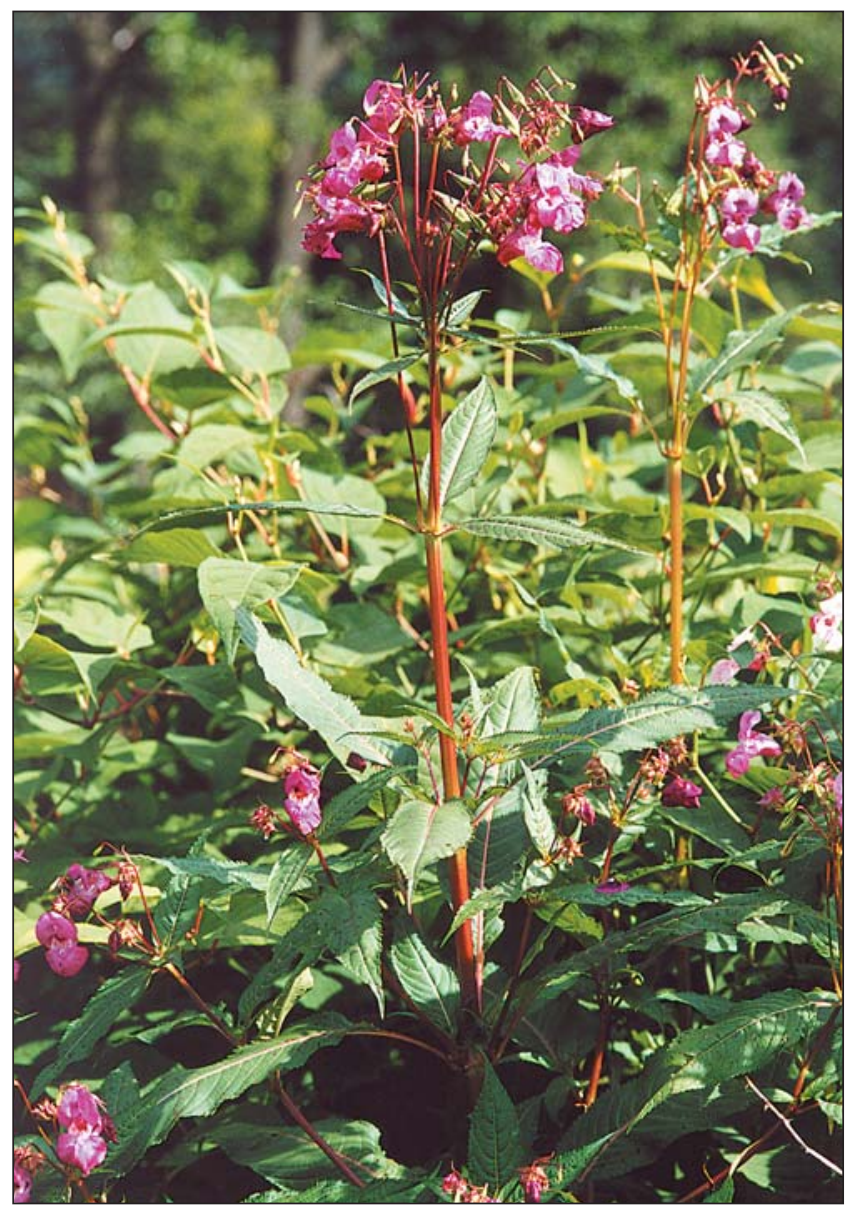

Fig. 2. Impatiens glandulifera (a).

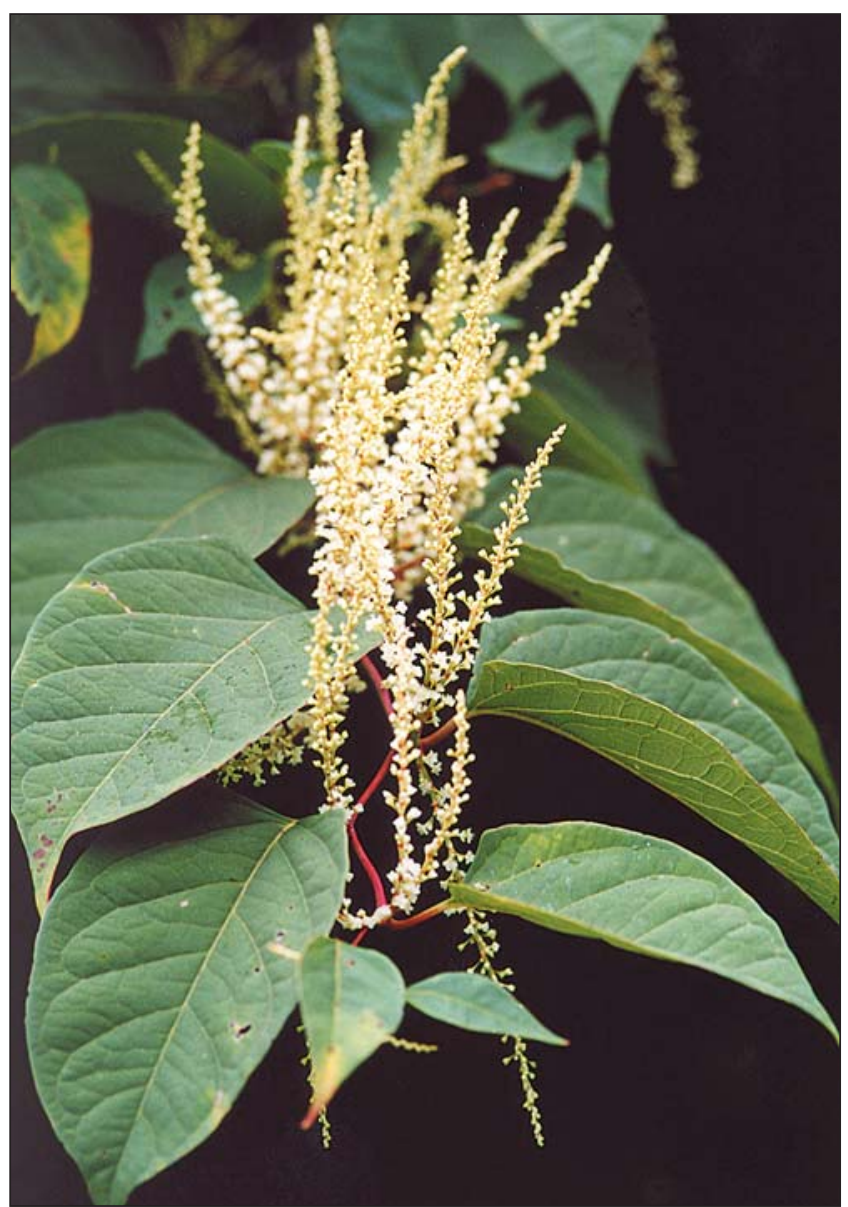

Fig. 4. Reynoutria japonica (a).

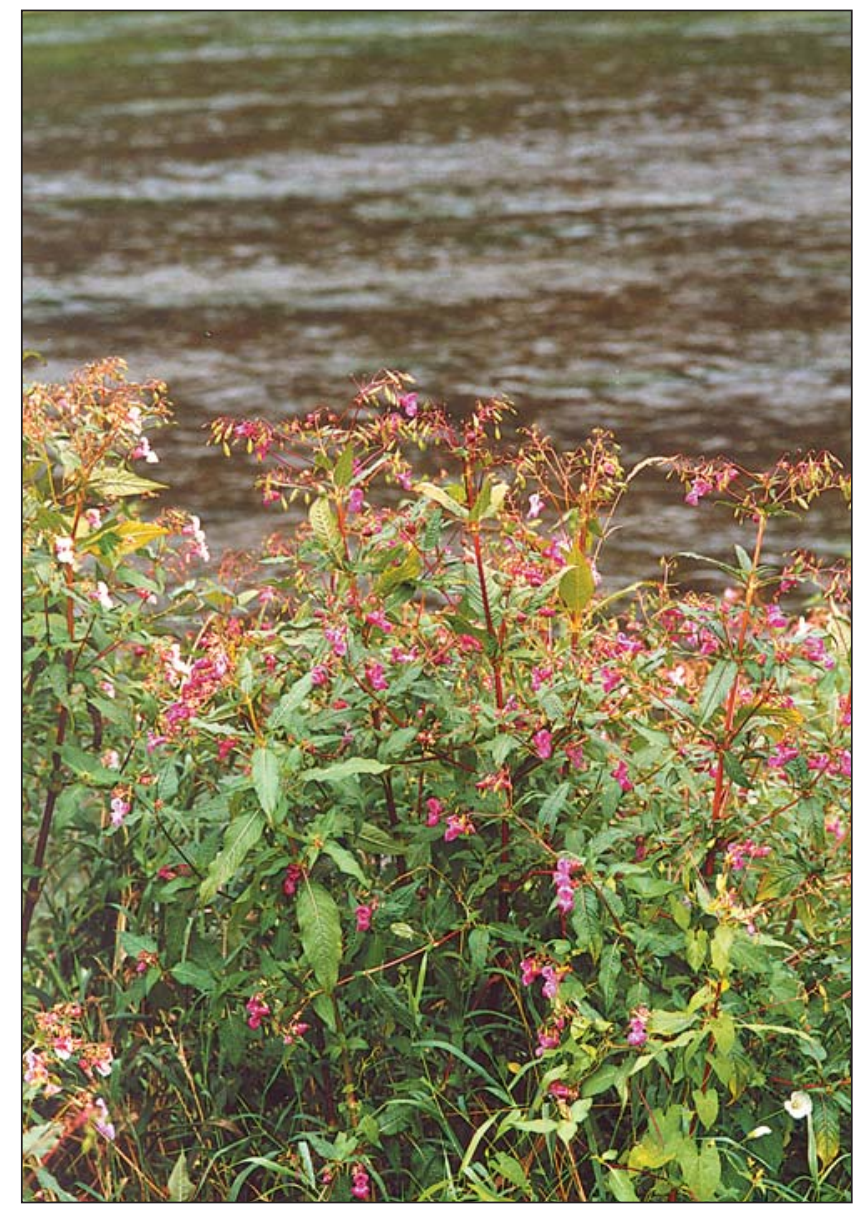

Fig. 3. Impatiens glandulifera (b).

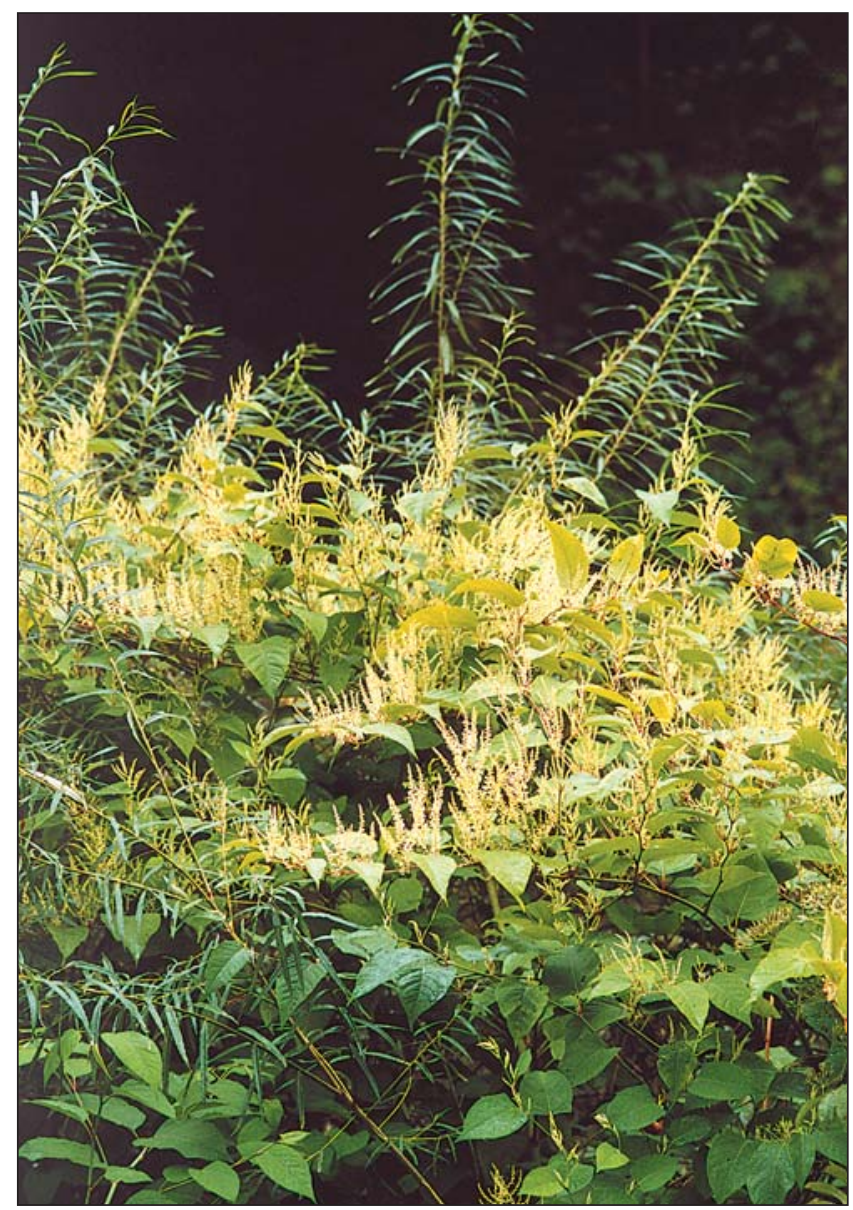

Fig. 5. Reynoutria japonica (b). 

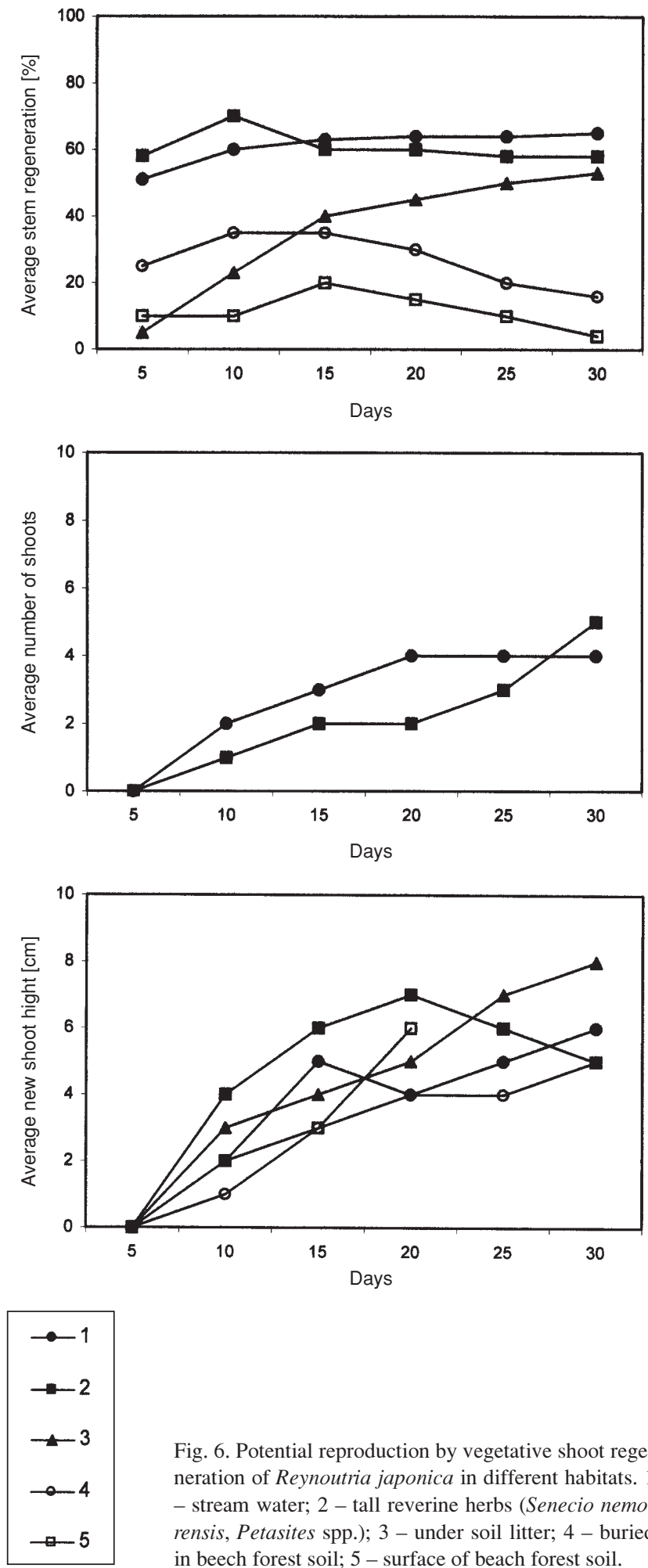

Fig. 6. Potential reproduction by vegetative shoot regeneration of Reynoutria japonica in different habitats. 1 - stream water; 2 - tall reverine herbs (Senecio nemorensis, Petasites spp.); 3 - under soil litter; 4 - buried in beech forest soil; 5 - surface of beach forest soil.

river valleys of the whole piedmont region. In the Karkonosze it makes as yet a threat only on the edges of the main massif, but advances intensively higher and higher, threatening the local flora. Photogrammetric pictures show the river valleys looking as they were filled by Reynoutria thickets. The success of species of genus Reynoutria in covering new territories is caused mainly by the unusual rate of vegetative growth (Baily and Connolly 2000; Holingworth and Bailey 2000; Bailey 2003). The intense increment and other peculiarities connected with Reynoutria's biology have been discussed in earlier papers (Brock et al. 1995; Fa- biszewski and Brej 2005). Recently we evaluated anew the possibilities of vegetative reproduction through vegetative regeneration of stems (Brock and Wade 1992; Brock et al. 1995). In spring and autumn we transferred fragments of stems, consisting of two nodes and three internodes, into five different habitats (Fig. 6). The stems were placed among others in stream water, in soil and on its surface and covered them partially by bedding.

Apart of appearance of adventitious roots and leaf-buds, sections of stems - particularly in moist places (riverine tall herbs) - lengthened in internodes.

A similar effect was obtained with rhizomes placed in moist soil and slightly covered with leaf bedding. The mean increment in length of stem segments from different variants of the experiment (various habitats) was $13.2 \mathrm{~cm}$ after three month duration of the experiment in the springsummer period.

The series of experiments lasting 30 days is presented in Figure 6. Most interesting is the third graph (from foot), showing the average number of new shoots, which grew on stems placed in the bed of the stream Szklarka - in water and among tall herbs. As is seen, after 30 days of the experiment all the stems were on average by $5.8 \mathrm{~cm}$ longer and had 4-5 shoots of green leaves. These experiments show, that successfully, that is by taking root, the ripped of shoot fragments may end their transport along the streambed. Then, at least some of the shoots may settle on the wet, eroded banks among tall herbs or in wet forests of AlnoPadion. In the latter, partially buried in soil, may facilitate the survival of living stems, saving them from drying up. The attempts of planting even previously rooted stems in beech and spruce forests ended with loss of their vitality already after ca. 10 days. We have also not confirmed the rather questionable reports (Brock at al. 1995) on the existing possibility to produce new root and leaf primordia by fragments of internodes from branches of Reynoutria. That observation concerned probably very young stems with exceptionally active intercalary meristem.

We also dealt with the dynamics of Reynoutria's biomass increment on the yearly scale, using the method described by Horn (1997). He analyzed the yearly biomass increment in Japanese Knotweed in the Czech Republic. The yearly rhythm of increment of aerial biomass of shoots and leaves in the Karkonosze is presented in Figure 7. The growing lowest (a) clusters of Reynoutria (550 m a.s.1.) are the juvenile clones, probably of a short residence period. They are characterized by a stable biomass of shoots and a relatively small biomass of leaves in yearly scale, in comparison with the total biomass of shoots. The next site (b), situated beneath a take-off for ski jumping, is a population partially cut every year. The shoot biomass is there stable, distinguished by a high increment (almost by leaps) of leaf mass in spring. In the spring period the biomass of leaves equals a half of the total biomass of shoots. The highest situated (870 $\mathrm{m}$ a.s.1.) cluster (c) differs in a late development, and thus with a low initial biomass. In the later vegetation period, the biomass of leaves increases distinctly, and then decreases (because of the short vegetation period), suggesting that resources are accumulated in late autumn more in stems than in leaves. The last diagram (d) presents the situation in biomass increment, typical for medium locations and for rich habitats (stream-bed Szklarka). This diagram is convergent with Horn's (1997) data, in spite of the hi- 

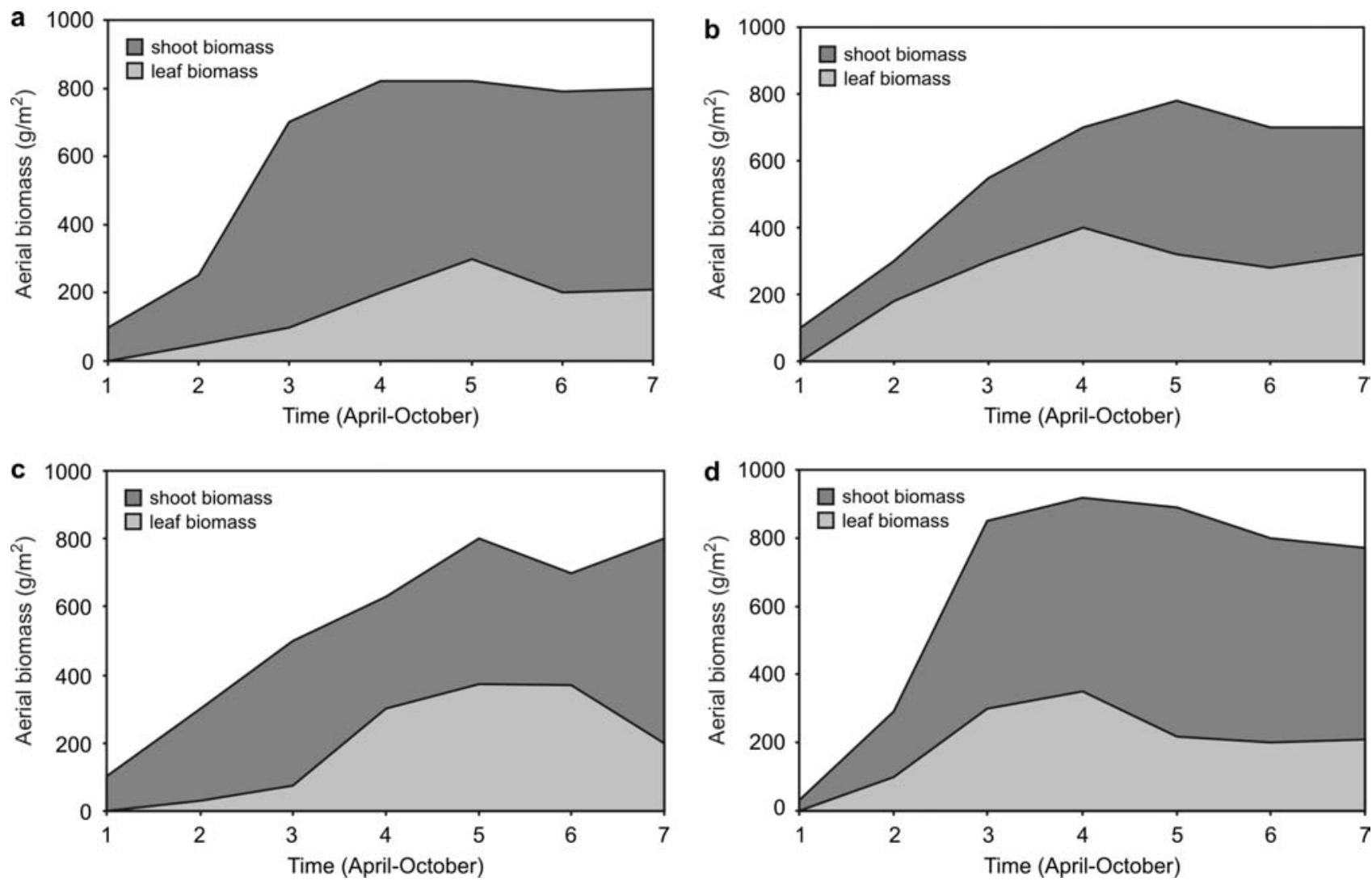

Fig. 7. Dynamics of aerial biomass of Reynoutria japonica in different stands. a - juvenile clones at $550 \mathrm{~m}$ elevation; $\mathrm{b}-$ population under ski tower; $\mathrm{c}-$ upmost population at $870 \mathrm{~m}$ elevation; $\mathrm{d}$ - typical reverine population; 1 - 7 seasonal samples.

gher location of Reynoutria specimens in the Karkonosze. This may impinge on a lower biomass increment. Many authors stress the sensitivity of Japanese Knotweed to ground frost in spring and autumn, that - as one can see in the Karkonosze belts, do not cause significant losses and do not reduce the plant's general vitality. Figure 7 (d) shows that the Knotweed biomass reveals and instant increment during the year. The plants achieve the highest biomass at the end of June (up to $900 \mathrm{~g} / \mathrm{m}^{2}$ ) - at leaf biomass of about $300 \mathrm{~g} / \mathrm{m}^{2}$, usually not reaching one third of the total mass of shoots. Only periodical cutting of shoots may stimulate the leaf biomass in the subsequent seasons - like in site (b). The typical relation between amount of biomass of leaves and shoots lasts until September, reaching at the end of the month a slight rise - less leaves and less shoots, but "heavier ones" by the accumulated reserve materials. The simultaneously investigated density of Knotweed shoots fluctuated from 20 to $30 / \mathrm{m}^{2}$. However, the separateness of shoots is difficult to evaluate, because of their multilateral clone connections. In densest shoots a self-thinning takes place, compensated by a more frequent appearing of new individuals on the edges of the clone.

There are no data on the influence of Reynoutria,s litter upon local plants; so far also no allelopatic influence restricting the accompanying plants was recorded. In our pilot experiments we have not recorded any allelopatic influence of litter on germination of Petasites albus and Senecio nemorensis. But the high density of Reynoutria thickets together with the formation of the layer of litter usually efficiently eliminates the germination and development of understory plants. In the Karkonosze, among plants eliminated by the Japanese Knotweed, which exhibits a strong growth vigor, belong the numerous early-spring, streamside and flooded forest geophytes.

\section{CONCLUSIONS}

The exact time of appearance of the studied invaders in the Sudety national parks is not known. From the several year observations it results that the present rate of spreading of both Impatiens glandulifera and Reynoutria japoni$c a$ has gained a character of disaster, which endangers also seriously the local flora and vegetation. This concerns particularly the Karkonosze National Park, where the propagule pressure of kenophytes and anthropogenic disturbance of habitats are especially strong and conductive to invasion. The different characteristics of the studied kenophytes determine the possibilities of occupying new territories. In Table 2 given are the most important characteristics determining the differences in life history of the investigated species.

The investigated species enlarge effectively the area of occurrence in the whole Sudety, using the generative growth strategy (Impatiens) and the vegetative way of reproduction (Reynoutria). However, in spite of the stressed by many authors sensitivity to the spring and autumn ground frosts, both the plants reach already the upper mountain belt (Impatiens - $900 \mathrm{~m}$ a.s.1., Reynoutria - 1025 $\mathrm{m}$ a.s.1.). In the vegetative way of plant spreading one ought to take under consideration the possibility of rooting of shoots in the lower nodes (Impatiens) and the, underestimated by researchers, ability of branches to take root and to form new shoots on them (Reynoutria). 
TABLE 2. Comparison of life histories of two invasive species.

\begin{tabular}{ll}
\hline Impatiens glandulifera & Reynoutria japonica \\
\hline Summer-annual therophyte & Clonal geophyte \\
Large purple-pink flowers & Small white flowers in racemes \\
Flowers from July until October & Flowers from August till September \\
Insect-pollinated and self-pollinated & No pollination (lack of male flowers) \\
Large numbers of seeds (over 2000 per plant) & No seeds \\
Seed float, latter sunk and deposited & No seeds \\
No persistent seed bank & No seed bank \\
Not spread by roots & Spreads by rhizome fragments \\
Cut stems do root at lower nodes & Cut stems root and regenerate on nodes under certain conditions \\
\hline
\end{tabular}

The considerable seed production in Impatiens, which ensures the invader the settling success, results from the permanent setting of seeds and fruits, from July to October. After winter chilling, the seeds germinate in great quantities in water and in wet habitats, particularly on eroded stream shores, sporadically also in wet forests (e.g. in beech forest).

We did not find in field nor in laboratory conditions (germination), the negative allelopatic influence of litter of both the plants upon the local species. During direct observation of competition effects, we recorded an inhibition of growth in Mercurialis perennis and Galium rotundifolium (Impatiens), as well as lack of spring geophytes (e.g. Anemone nemorosa and Corydalis spp) on litter and under canopy of Reynoutria.

The periodical cutting of shoots in Japanese Knotweed (particularly in spring), increased its biomass in the following year. The highest biomass was attained by Reynoutria at the end of June (up to $900 \mathrm{~g} / \mathrm{m}^{2}$ ) at leaf biomass of about $300 \mathrm{~g} / \mathrm{m}^{2}$, usually not reaching one third of the total mass of shoots.

Our investigations confirm the great invasive strength of the analyzed species. A further spreading of both the invaders, especially in the Karkonosze National Park, will make a serious threat for local plants, the elimination of which may contribute to the decline of the park's scientific values. However, we have not found any threat from invader plants for the second investigated park - the Stołowe Mts National Park. Fortunately, R. japonica and I. glandulifera are growing beyond the park area, crossing nowhere its limits.

\section{ACKNOWLEDGEMENTS}

This work was supported by the Polish Ministry of Science and Higher Education, grant no. 3 P04G 08525 (2003-2008).

\section{LITERATURE CITED}

BAILEY J.P, CONOLLY A.P. 2000. Prize-winners to pariahs a history of Japanese Knotweed s.l. (Polygonaceae) in the British Isles. Watsonia 23: 93-110.

BAILEY J.P. 2003. Japanese Knotweed s.l. at home and abroad. In: Plant Invasions - Ecological Threates and Management Solutions, (eds) Child L., Brock J.H., Brundu G., Prach K., Pyšek P., Wade P.M., Williamson M., Backhuys Publ., Leiden, p. 183-196.

BEERLING D.J., BAILEY J.P., CONOLLY A.P. 1994. Biological flora of the British Isles: Fallopia japonica (Houtt). Rouse Decraena. J. Ecol. 82: 959-979.
BEERLING D., PERRINS J.M. 1993. Biological flora of the Britsh Isles: Impatiens glandulifera Royle. J. Ecol. 81: 367-382.

BROCK J.H., CHILD L.M., de WALL L.C., WADE M. 1995. The invasive nature of Fallopia japonica is enhanced by vegetative regeneration from stem tissues. In: Plant Invasions - General Aspects and Special Problems. Pyšek P., Prach K., Rejmánek M., Wade M. (eds), SPB Academic Publ., Amsterdam, p. 131-139.

BROCK J.H., WADE P.M. 1992. Regeneration of Japanese Knotweed (Fallopia japonica) from rhizomes and stems: observation from greenhouse trials. Proceedings of the 9th Int. Symp. Biol. Weeds: 85-94. Dijon.

di CASTRI F., HANSEN A.J., DEBUSSCHE M. 1989. Biological Invasions in Europe and the Mediterranean Basin. Kluwer Academic Publ., Dordrecht.

CRAWLEY M.J. 1987. What makes a community invasible? In: Colonization Succession and Stability. (eds) Grey A.J., Crawley M.J., Edwards P.J. Blackwell Sci. Publ., Oxford, p. 429-454.

CRONK Q.C.B., FULLER J.L. 1995. Plant Invaders. The Threat to Natural Ecosystems. Chapman \& Hall, London.

DRAKE J.M., MOONEY H.A., di CASTRI F., GROVES R.H., KRUGER F.J., REJMÁNEK M., WILLIAMSON M. 1989. Biological Invasions: A Global Perspective. Scope 37. John Wiley, Chichester.

FABISZEWSKI J., BREJ T. 2005. Agresywni przedstawiciele kenofitów w Karkonoszach [Aggresive kenophytes in the Karkonosze Mts]. Ann. Silesiae 34: 115-121. (in Polish with English summary)

FABISZEWSKI J., BREJ T. 2007. Agresywni przedstawiciele kenofitów w Karkonoszach. Cz. II. Inwazje na tle odmiennych siedlisk [Aggresive kenophytes in the Karkonosze Mts. Part II. Invasion in different habitats]. Ann. Silesiae 35: 97-104. (in Polish with English summary)

FABISZEWSKI J., KWIATKOWSKI P. 2001. Gatunki inwazyjne we florze naczyniowej Sudetów [Invasive plant species from the Sudety Mts]. Ann. Silesiae 31: 123-127. (in Polish with English summary)

FALIŃSKI J.B. 1998. Invasive alien plants. Vegetation dynamics and neophytism. Phytocoenosis N.S. 10 Suppl. Cartogr. Geobot. 9: 163-187.

HIERRO L., MARON J.L., CALLAWAY R.M. 2005. A biogeographical approach to plant invasions: the importance of studying exotics and their introduced and native range. J. Ecol. 93: 5-15.

HOLLINGSWORTH M.L., BAILEY J.P. 2000. Evidence for massive clonal growth in the invasive weed Fallopia japonica (Japanese Knotweed). Bot. J. Linn. Soc. 133: 463-472.

HORN P. 1997. Seasonal dynamics of aerial biomass of Fallopia japonica. In: Plant Invasions: Studies from North America and Europe. Brock J.H., Wade M., Pyšek P., Green D. (eds). Backhuys Publ., Leiden, p. 203-206.

KOLLMANN J., BAŃUELAS M.J. 2004. Latitudinal trends in growth and phenology of the invasive alien plant Impatiens glandulifera (Balsaminaceae). Diversity Distrib. 10: 377-385.

LONSALE W.M. 1999. Global patterns of plant invasions and the concept of invisibility. Ecology 80: 1522-1536. 
MACDOUGALL A.S., TURKINGTON R. 2005. Are invasive species the drivers or passengers of change in degradated ecosytems? Ecology 86: 42-55.

MAULE H., ANDREWS M., WATSON C., CHERRIL A. 2000. Distribution, biomass and effect on native species of Impatiens glandulifera in a deciduous woodland, northeast England. Aspects Appl. Biol. 58: 31-38.

NENTWIG W. (ed.). 2007. Biological Invasions. Ecological Studies 193. Springer Verlag, Berlin, Heidelberg.

PYŠEK P., PRACH K. 1995. Invasion dynamics of Impatiens glandulifera - a century of spreading reconstructed. Biol. Conserv. 74: 41-48.

PYŠEK P., RICHARDSON D.M. 2007. Traits associated with invasiveness in alien plants: where do we stand? Ecol. Stud. 193: 97-125.

PERRINS J., FITTER A., WILLIAMSON M. 1993. Population biology and rates of invasion of three introduced Impatiens species in the British Isles. J. Biogeogr. 20: 33-44.

STARFINGER U., EDWARDS K., KOWARIK I., WILLIAMSON M. (eds). 1998. Plant Invasions: Ecological Mechanisms and Human Response. Backhuys Publ., Leiden.
THEOHARIDES K.A., DUKES J.S. 2007. Plant invasion across space and time: factors affecting nonindigenous species success during four stages of invasion. New Phytol. 176: 256-273.

TOKARSKA-GUZIK B. 2005. The establishment and spread of alien plant species (kenophytes) in the flora of Poland. Wydawnictwo Uniwersytetu Śląskiego, Katowice.

WADE P.M. 1997. Predicting plant invasions: making a start. In: Plant Invasions: Studies from North America and Europe. (eds) Brock J.H., Wade M., Pyšek P., Green D. Backhuys Publ., Leiden, p. 1-18.

de WALL L.C., CHILD L.E., WADE P.M., BROCK J.H. (eds). 1994. Ecology and Management of Riverside Plants. John Wiley \& Sons, Chichester.

WILLIS S.G., HULME P.E. 2004. Environmental severity and variation in the reproductive traits of Impatiens glandulifera. Func. Ecol. 18: 887-898.

ZAJĄC A., ZAJĄC M., TOKARSKA-GUZIK B. 1998. Kenophytes in the flora of Poland: list, status, origin. Phytocoenosis N.S. 10 Suppl. Cartogr. Geobot. 9: 107-116. 